\title{
A STUDY OF MICROBIOLOGICAL CONTAMINATION OF MOBILE PHONES IN OPERATING ROOM PERSONNEL AND EFFICACY OF DECONTAMINATION WITH 2\% ISOPROPYL ALCOHOL
}

\author{
Shivakumar M. Channabasappa1, Gopinath H. Venkatarao², Shruthi Dharmappa ${ }^{3}$ \\ ${ }_{1}^{1}$ Associate Professor, Department of Anaesthesiology, Subbaiah Institute of Medical Sciences. \\ ${ }^{2}$ Assistant Professor, Department of Surgery, Subbaiah Institute of Medical Sciences. \\ ${ }^{3}$ Senior Lecturer, Department of Oral Pathology, Subbaiah Institute of Medical Sciences.
}

\section{ABSTRACT}

\section{BACKGROUND}

The objective of this study was to determine the contamination rate of the healthcare workers' (HCWs') mobile phones in operating room and identify strategies for their safe use within clinical areas. This study also to determine whether a standardized disinfecting protocol decreased the rate of bacterial contamination.

\section{METHODS}

This is a cross-sectional study that included all Health care workers with mobile phones in operation theatre. Samples for culture were collected from mobile phones with swab stick before and after disinfection of mobile phones with $2 \%$ isopropyl alcohol swab and transported for microbiological identification using Amies medium. Quantification of bacteria was performed using both surface spread isolated bacterial agents were identified using standard microbiological methods.

\section{RESULTS}

Total of 92 samples studied from 46 mobiles, out of 46 mobile phones tested (89\%) 41 were contaminated with either single or mixed bacterial agents. The most prevalent bacterial contaminants were Coagulase-Negative Staphylococci (CONS) and E. coli representing $36 \%$ and $23 \%$, respectively. After cleaning of mobile phone with $2 \%$ isopropyl alcohol decreases contamination to $50 \%$. The mean bacterial count was $357 \mathrm{CFU} / \mathrm{ml}$, while the median was $13 \mathrm{CFU} / \mathrm{ml}$ using the pour plate method. The corresponding figures were 2,192 and 1,720 organisms/phone using the surface spread method.

\section{CONCLUSION}

It is important to be conscious of the fact that mobile phone usage in Operation Theater is easily contaminated. Because cleaning with alcohol swabs prevents the contamination of the mobile phones. Mobile communication devices have an invaluable feature of communication within hospital health care providers should take standard precautions to minimize the contamination of mobile phones.

\section{KEYWORDS}

Mobile Phones, Bacterial Contamination, Isopropyl Alcohol.

HOW TO CITE THIS ARTICLE: Channabasappa SM, Venkatarao GH, Dharmappa S. A study of microbiological contamination of mobile phones in operating room personnel and efficacy of decontamination with $2 \%$ isopropyl alcohol. J. Evolution Med. Dent. Sci. 2016; 5(10):438-441, DOI: 10.14260/jemds/2016/100

\section{INTRODUCTION}

Global burden of Hospital-Associated Infection (HAI) is on the rise and contributes significantly to morbidity and mortality of the patients. ${ }^{1}$ Mobile communication devices have an invaluable feature of communication within hospital and they may support certain aspects of clinical diagnosis and education. ${ }^{2}$ Mobile smart phones have become increasingly integrated into the practice of doctors and allied medical professionals.

When first evidence on the dangers of electronic interference associated with mobile phones appeared in the 1990s, hospitals in many countries introduced complete bans on mobile phones.

Financial or Other, Competing Interest: None.

Submission 10-01-2016, Peer Review 18-01-2016,

Acceptance 22-01-2016, Published 04-02-2016.

Corresponding Author:

Dr. Shivakumar M. Channabasappa,

SSS Mansion, $3^{\text {rd }}$ Cross,

Basaveswara Nagar, Shimoga-577201.

E-mail: drshivakumar.m.c@gmail.com

DOI:10.14260/jemds/2016/100
Yet a review of recent evidence suggests that there is no significant risk from using mobile phones in hospitals as long as they are more than a meter away from sensitive equipment, whereas the risk to the most modern equipment is even less. With the technological evolution of mobile phones, the residual risk of interference appears to be minimal and controllable. Although some countries are reluctant to relax regulation, others now limit bans to areas in which sensitive equipment is used and some discourage the use of mobile phones on the grounds of noise exposure.

Recent studies suggest them to represent reservoirs for pathogens with potential to cause nosocomial infections.(3-5) The benefit of using mobile phones in the OR should be weighed against the risk for unperceived contamination. The potential benefit of using mobile phones by the personnel for private communication or emergency situations in OR would change into this means of communication detrimental to hospital hygiene. Therefore, near the hand hygiene, cleaning of these devices should be kept in mind. Prevention of contamination risk of nosocomial pathogens and infections stands out as problem that must be weighed in mind. 
The use of mobile phones may have more serious hygiene consequences, because unlike fixed phones, mobile phones are often used in the OR close to the patient with the potential to undermine infection control efforts aimed at the reducing bacterial cross-contamination in hospitals. During every phone call the mobile phones come into close contact with strongly contaminated human body areas with hands to hands and hands to other areas (Mouth, nose, ears). Herein mobile phones are particularly problematic when compared to immobile devices and it may facilitate transmission of bacterial isolates.

This potential could be amplified further when employers require doctors to carry additional electronic devices for communication without concurrently providing appropriate guidance on decontamination or use.(6)

The risk of infection involved in using mobile phones in the OR has not yet been determined as there are no cleaning guidelines available that meet hospital standards. However, the mobile phones are used routinely all day long, but not cleaned properly as health care workers (HCW) may not wash their hands as often as they should.

Developing active preventive strategies like routine decontamination of mobile phones with alcohol containing disinfectant materials might reduce cross-infection. Another way of reducing bacterial contaminations on mobile phones might be the use of antimicrobial additive materials. We could easily avoid spreading bacterial infections just by using regular cleansing agents and rearranging our environment. In the future mobile phones could be produced by using protective material against the bacterial contamination.

\section{MATERIALS AND METHODS}

This randomized double blind, cross-sectional study was carried out between October 2015 and December 2015 Sample size selection was calculated using a 95\% confidence level and a 5\% error around the expected prevalence and an alpha error of $5 \%$, the resulting minimum sample size required amounted to 42 mobile phones.

A total of 92 samples from 46 mobile phones of HCWs of different operation theater were tested for their bacterial contamination before and after cleaning with isopropyl alcohol. Sample selected were randomly allocated one of the two groups.

Group 1: Sample collected from mobile phone before disinfection.

Group 2: Sample collected from mobile phone after cleaning with $2 \%$ isopropyl alcohol.

The examined mobile phones were randomly collected. A questionnaire was used for data collection of all the relevant information on tested mobile phones.

\section{Samples Collection and Processing}

Samples from mobile phones were collected using sterile cotton swab stick. Each swab was first moistened with sterile normal saline and was rotated over the surface of both sides of the tested mobile phone together with the keypad or touch screen. All swabs were immediately transported using Amies Transport Media. All samples were inoculated blood and MacConkey's Agar plates (Oxoid, UK) and then were incubated at $37^{\circ} \mathrm{C}$ for 48 hours. All plates were examined for visible growth. Based on colonial morphology, Gram stain and different biochemical reactions, isolates were allocated to appropriate general. Isolated bacterial agents were identified using Gram's staining, colony morphology and biochemical tests. For identification of Gram-Positive Cocci (GPC); isolates that appeared as medium sized circular, white or golden yellow with smooth convex surface and entire edge and were $\beta$-hemolytic or non-hemolytic on blood agar plates and were positive for catalase, slide and tube coagulase and Voges Proskauer tests were considered as Staphylococcus aureus (S. aureus). Non-haemolytic, catalase-positive, coagulasenegative, bacitracin-sensitive GPC were identified as Micrococcus spp., while catalase-positive, coagulase-negative and bacitracin-resistant GPC were considered as coagulasenegative staphylococci (CoNS).

S. aureus and CoNS identified isolates were further checked for their susceptibility to methicillin using oxacillin $(1 \mu \mathrm{g})$ and cefoxitin $(30 \mu \mathrm{g})$ discs on Mueller Hinton Agar plates supplemented by $4 \% \mathrm{NaCl}$ by disk diffusion method described by Bauer and Kirby.[7]

Data were analysed using SPSS version 16.0, the 0.05 level was used as the cut off value for statistical significance. Variables were presented as number and percentage.

\section{RESULTS}

The study was conducted on 46 mobile phones from doctors and HCWs at our teaching hospital.

This study enrolled the mobile phones of $13(28 \%)$ paramedic staff, 6 (13\%) non-technical staff and 27 (58\%) doctors (Table-1); 36 (78\%) of these cell phones were touch screen phones. (Table-2) The majority of these mobile phones did not have covers 32 (69\%). This study revealed that the majority of isolated bacterial contaminants were mixed with more than one organism in Group 1, 41 (89\%) as compared to only 23 (50\%) in Group 2; 17 (37\%) of Group 1 mobile phones were contaminated with CONS as compared to $8(17 \%)$ in Group 2 (Table-3), which was statistically significant.

Rate of Bacterial Isolation and Efficacy of 2\% isopropyl alcohol: From 46 mobile phones sampled in this study 41 were contaminated with bacteria before decontamination, 41 mobile phones showed contamination with multiple bacterial species. A total of 14 bacterial isolates were identified from these mobile phones. From the isolates Gram-positive bacteria accounted for $77.9 \%$, coagulase negative staphylococci being the most frequently (37\%) isolated bacteria followed by methicillin sensitive S. Aureus (17.1\%) and methicillin resistant S. Aureus (10\%). E.coli (23\%) was the most frequently isolated Gram-negative bacteria followed by pseudomonas species accounted for $2 \%$ of the isolates (Table 4). When the rate of bacterial isolation was evaluated after decontamination with $70 \%$ alcohol from the mobile phones assessed growth was observed in 23 (50\%) mobile phones. In this study $2 \%$ isopropyl alcohol brought a significant reduction in the rate of mobile phone contamination with $\mathrm{p}$ value of $<0.0001$ (Table 4).

\begin{tabular}{|c|c|c|c|}
\hline $\begin{array}{c}\text { No. of } \\
\text { Bacterial } \\
\text { Agents (CFU) }\end{array}$ & Doctors & Paramedic & $\begin{array}{c}\text { Non- } \\
\text { technical } \\
\text { Staff }\end{array}$ \\
\hline 0 & 3 & 2 & 0 \\
\hline $1-10$ & 6 & 5 & 2 \\
\hline $11-100$ & 5 & 2 & 1 \\
\hline $101-1000$ & 3 & 2 & 0 \\
\hline$>1000$ & 10 & 2 & 3 \\
\hline
\end{tabular}

Table 1: Bacterial contamination of mobile phones among different operating room personnel 


\begin{tabular}{|c|c|c|}
\hline $\begin{array}{c}\text { No. of Bacterial } \\
\text { Agents (CFU) }\end{array}$ & Touch Pad Phone & Key Pad Phones \\
\hline 0 & 5 & 0 \\
\hline $1-10$ & 8 & 5 \\
\hline $11-100$ & 7 & 1 \\
\hline $101-1000$ & 5 & 0 \\
\hline$>1000$ & 10 & 5 \\
\hline \multicolumn{2}{|c|}{ Table 2: Bacterial Isolates among different type of } \\
mobile phones (Touch pad vs keypad) \\
\hline
\end{tabular}

\begin{tabular}{|c|c|c|}
\hline $\begin{array}{c}\text { No. Of } \\
\text { Bacterial } \\
\text { Agents(CFU) }\end{array}$ & $\begin{array}{c}\text { Before } \\
\text { Decontamination }\end{array}$ & $\begin{array}{c}\text { After } \\
\text { Decontamination }\end{array}$ \\
\hline 0 & 5 & 23 \\
\hline $1-10$ & 13 & 13 \\
\hline $11-100$ & 8 & 4 \\
\hline $101-1000$ & 5 & 1 \\
\hline$>1000$ & 15 & 5 \\
\hline \multicolumn{2}{|c|}{ Table 3: Number of bacterial isolates from mobile } \\
phones before and after decontamination with 2\% \\
isopropyl alcohol \\
\hline
\end{tabular}

\begin{tabular}{|c|c|c|}
\hline $\begin{array}{c}\text { Bacterial } \\
\text { Agents }\end{array}$ & $\begin{array}{c}\text { Before } \\
\text { Decontamination } \\
\end{array}$ & $\begin{array}{c}\text { After } \\
\text { Decontamination } \\
\end{array}$ \\
\hline $\begin{array}{c}\text { Mithicillin } \\
\text { resistant staph. } \\
\text { aureas (MRSA) }\end{array}$ & $5(10 \%)$ & $4(8.6 \%)$ \\
\hline $\begin{array}{c}\text { Mithicillin } \\
\text { sensitive staph. } \\
\text { aureas (MSSA) }\end{array}$ & $8(17 \%)$ & $4(8.6 \%)$ \\
\hline E. Coli & $11(23 \%)$ & $2(4.3 \%)$ \\
\hline Bacillus spp. & $3(6.5 \%)$ & $1(2 \%)$ \\
\hline Acinetobacter & $2(4.3 \%)$ & $1(2 \%)$ \\
\hline Pseudomonas & $1(2 \%)$ & 0 \\
\hline Aspergilla & $1(2 \%)$ & $1(2 \%)$ \\
\hline $\begin{array}{c}\text { Coagulase } \\
\text { negative Staph } \\
\text { aureaus(CONS) }\end{array}$ & $17(36 \%)$ & $8(17 \%)$ \\
\hline Viridans & $2(4.3 \%)$ & 0 \\
\hline
\end{tabular}

\section{DISCUSSION}

This study demonstrated that $89 \%$ of the mobile phones of health care workers were contaminated with bacteria. As compared to the current study lower values were reported from Saudi Arabia (43.6\%), Iran (32\%), Turkey (61.3\%) and Nigeria (62\%).[8,9] The difference observed may be attributed to the difference in implementation of infection prevention strategies as most of the studies were conducted in Intensive Care Units while our study was conducted in operation theatres. Moreover, most of the study participants never cleaned their mobile phones, which will contribute to the increased contamination rate. On the other hand, relatively similar results were reported from other parts of the world including Turkey (94.5\% and 90.98\%), India (95\%).[10]

When the types of organisms isolated are considered despite the difference in the isolation rate, most studies had reported similar types of organisms.[11] S. aureus and CoNS were the most frequently isolated organisms in those studies, which is in line with our report. Similar to this result other studies have also demonstrated the presence of these bacteria as contaminants of health care workers mobile phones. On the other hand, other studies reported organisms like Klebsiella species, Neisseria species and enterococci species which were not isolated in this study.[12]

The efficacy of decontamination with $2 \%$ isopropyl alcohol was found to be $50 \%$. This result was lower than a study conducted elsewhere in the world, which showed decontamination efficacy of $98 \%$ with $70 \%$ isopropyl alcohol.[13] Though the efficacy in our study is low still significant decrement in the rate of contamination was observed ( $p$-value $<0.0001$ ). This suggests that the use of this decontaminating agent will have an important value in reducing bacterial colonization of health care workers mobile phones, thus decreasing transmission of the bacteria to the patients.

\section{CONCLUSION}

Developing active preventive strategies like routine decontamination of mobile phones with alcohol containing disinfectant materials might reduce cross-infection. Another way of reducing bacterial contaminations on mobile phones might be the use of antimicrobial additive materials. We could easily avoid spreading bacterial infections just by using regular cleansing agents and rearranging our environment.

\section{REFERENCES}

1. Sallam SA, Arafa MA, Razek AA, et al. "Device-related nosocomial infection in intensive care units of Alexandria University Students Hospital." Eastern Mediterranean Health Journal 2005;11:52-60.

2. Ramesh J, Carter AO, Campbell MH, et al. "Use of mobile phones by medical staff at Queen Elizabeth Hospital, Barbados: evidence for both benefit and harm." Journal of Hospital Infection 2008;70:160-65.

3. Arora U, Devi P, Chadha A, et al. "Cellphones a modern stay house for bacterial pathogens." JK Science 2009;11:127-29.

4. Chawla K, Mukhopadhayay C, Gurung B, et al. "Bacterial "Cell" phones: do cell phones carry potential pathogens?" Online Journal of Health and Allied Sciences 2009;8:1-5.

5. Karabay 0, Koçoglu E and Tahtaci M. "The role of mobile phones in the spread of bacteria associated with nosocomial infections." The Journal of Infection in Developing Countries 2007;1:72-3.

6. Ulger F, Esen S, Dilek A, et al. "Are we aware how contaminated our mobile phones with nosocomial pathogens?" Annals of Clinical Microbiology and Antimicrobials 2009;8:1-4.

7. Bauer AW, Kirby WMM, Sherris JC, et al. Antibiotic susceptibility testing by a standardized single disk method. Am J Clin Pathol 1966;36:493-96.

8. Sepehri G, Talebizadeh N, Mirzazadeh A, et al. "Bacterial contamination and resistance to commonly used antimicrobials of healthcare workers' mobile-phones in teaching hospitals, Kerman, Iran." The American Journal of Applied Sciences 2009;6:806-10.

9. Akinyemi KO, Atapu AD, Adetona 00, et al. "The potential role of mobile phones in the spread of bacterial infections." Journal of Infection in Developing Countries 2009;3:628-32. 
10. Jayalakshmi J, Appalaraju B and Usha S. "Cellphones as reservoirs of nosocomial pathogens." Journal of Association of Physicians of India 2008;56:388-89.

11. Sadat-Ali M, Al-Omran AK, Azam Q et al. "Bacterial flora on cell phones of health care providers in a teaching institution." The American Journal of Infection Control 2010;38:404-05.
12. Gunasekara TDCP, Kudavidanage BP, Peelawattage MK, et al. "Bacterial contamination of anaesthetist's hands, personal mobile phones and wrist watches used during theatre sessions." Sri Lankan Journal of Anaesthesiology 2009;17:11-15.

13. Talbot GH, Skros M, Provencher M. 70\% alcohol disinfection of transducer heads: experimental trials. Infect Control 1985;6:237-39 [PubMed]. 